\title{
Firm Characteristics, Governance Attributes and Corporate Voluntary Disclosure: A Study of Jordanian Listed Companies
}

\author{
Khaldoon Albitar ${ }^{1}$ \\ ${ }^{1}$ School of Accounting and Finance, Zhongnan University of Economics and Law, Wuhan, China \\ Correspondence: Khaldoon Ghassan Albitar, Doctoral Student, School of Accounting and Finance, Zhongnan \\ University of Economics and Law, Wuhan, China. E-mail: bitar2012@yahoo.com
}

Received: November 2, 2014

Accepted: January 21, 2015

Online Published: February 25, 2015

doi:10.5539/ibr.v8n3p1

URL: http://dx.doi.org/10.5539/ibr.v8n3p1

\begin{abstract}
This paper focuses on the voluntary disclosure in corporate annual reports in Jordan, and its objectives are: (1) To measure the voluntary disclosure level in the annual reports of Jordanian companies listed in Amman Stock Exchange (ASE). (2) To examine the relationship between a number of explanatory variables and the level of voluntary disclosure. Unweighted disclosure index consisting of 63 voluntary items was developed to assess the level of voluntary disclosure in the annual reports of 124 listed companies on ASE for the period of 2010 to 2012. Univariate and Multivariate analysis were applied to explore the relationship between each explanatory variables and the level of voluntary disclosure and a number of sensitivity tests were taken to further analysis. The findings of the study reveal that the level of voluntary disclosure in Jordanian corporate annual reports is low (its average is $35.7 \%$ for three years), although there is a significant increase in the level of voluntary disclosure from year to year. Univariate analysis reveals that firm size, leverage, firm age, profitability, liquidity, board size and audit committee size have a significant positive relationship with the level of voluntary disclosure while independent directors and ownership structure have a significant negative relationship with the level of voluntary disclosure. Meanwhile, multivariate analysis reveals same results to Univariate analysis except leverage has no impact on the level of voluntary disclosure.
\end{abstract}

Keywords: voluntary disclosure, governance attributes, firm characteristics, Amman stock exchange

\section{Introduction}

Information should be prepared, audited, and disclosed in accordance with high quality accounting standards. Stakeholders and potential investors require access to regular, reliable and comparable information in details for them to assess the stewardship of management, and make informed decisions. A strong disclosure regime enhances transparency, and it is a powerful tool for influencing the behavior of stakeholders. It results in the attraction of more capital, sustains investors' confidence in the capital market, and possibly prevents fraud. Inadequate information may increase the cost of capital and result in a poor allocation of resources. Moreover, the business environment has witnessed changes over the years, mainly been influenced by globalization and technological innovation. Companies worldwide are now trying to penetrate international capital markets. Therefore, the disclosure of adequate and reliable information is necessary.

In recent years Amman Stock Exchange has experienced remarkable increases in trading volumes, market capitalization and the number of corporations listed on the market; for instance, market financial capitalization has almost tripled over the last five years. In addition, the market is expected to gain from the recent political development in the region, the importance of disclosure in a market economy cannot be overemphasized if scarce resources are to be distributed to their most productive uses. Further, it is widely acknowledged that the quality of investment decisions depends, to a large extent, on the quality and quantity of information available to investors. The general purpose of this study therefore is to extend our knowledge about the disclosure practices, mainly, voluntary disclosure, in corporate annual reports of Jordanian companies listed on the ASE.

\section{Literature Review and Hypotheses Development}

\subsection{Firm-Specific Characteristics}

\subsubsection{Firm Size}

The general hypothesis is that a company's disclosure practice is positively associated to its size. One of the 
reasons can support the positive effect of company size on corporate disclosure derived from the agency theory. Jensen and Meckling (1976) have confirmed that agency costs are likely to increase with the proportion of outside capital. Given that the proportion of outside capital tends to be higher for large companies, it is reasonable to speculate that large companies are more likely to provide more information in an attempt to reduce their agency costs. Several proxies have been suggested and used as measures of size like total assets, sales, and net income. Literature found evidence that larger firms disclose more information (Allegrini \& Greco, 2011; Bhayani, 2012; Alves et al., 2012).

$\mathrm{H}_{1}$ : There is a significant positive relationship between firm size of the firm and the level of voluntary disclosure found in annual reports.

\subsubsection{Leverage}

Leverage may influence the level of voluntary disclosure. For example, a high leverage ratio may improve disclosure policy for managers and encourage them to disclose more information to meet investors' interests. on the other hand, a low ratio could encourage managers to orient their disclosure procedure toward shareholders more than creditors. Accordingly, managers are motivated to disclose more data in their financial reports to lower their costs and to avoid any creditors' claims. A number of researchers did not find any relationship between leverage and the disclosure level (Aksu \& Kosedag, 2006). Nevertheless, other research found a positive relationship (Kolsi, 2012; Hajji \& Ghazali, 2013). In addition, other studies Allegrini and Greco (2011) Nandi and Ghosh (2012) Bhayani (2012) discovered a negative relationship between leverage and the disclosure level.

$\mathrm{H}_{2}$ : There is a significant positive relationship between leverage and the level of voluntary disclosure found in annual reports.

\subsubsection{Firm Age}

There are several theoretical grounds to assume that older companies are more likely to disclose more information than younger ones. For example, the competition argument proposes that young companies are not likely to disclose full information about their financial results and position, because this may prove to be detrimental if sensitive information is disclosed to the established competitors. In contrast, old companies are less likely to be motivated to withhold such information since their competitive advantages cannot be easily challenged with increased disclosure (Owusu, 1998). This is because they are long established and it is likely that the market is already aware of these advantages. Hossain and Hammami (2009) have found a positive relationship between firm age and the level of voluntary disclosure, other researchers did not find any relationship between Firm age and the level of voluntary disclosure (Bhayani, 2012), in our research firm age measured by number of years since foundation.

$\mathrm{H}_{3}$ : There is a significant positive relationship between firm age of the firm and the level of voluntary disclosure found in annual reports.

\subsubsection{Profitability}

There is a general proposition that a company's willingness to disclose information is positively related to its profitability. One motive for this can be derived from agency theory. It is suggested that managers of profitable companies disclose extensive information in order to show and explain to shareholders that they are acting in their best interests and justify their compensation packages. Previous studies employed different measures of profitability like return on total assets and return on equity. The findings of previous research regarding the relationship between profitability and voluntary disclosure using one or more of these measures are rather varied. Hossain and Hammami (2009), Kolsi (2012) and Bhayani (2012) indicated a significant positive relationship, while Glaum and Street (2003) provided no evidence of relationship between company profitability and level of voluntary disclosure.

$\mathrm{H}_{4}$ : There is a significant positive relationship between firm profitability and the level of voluntary disclosure found in annual reports.

\subsubsection{Liquidity}

Signaling theory suggests, according to Abd-Elsalam (1999) that firms enjoying a high liquidity ratio are disposed to disclose more information to be distinguished from other companies suffering from a lower liquidity ratio. On the other hand, agency theory argues that firms with a low percentage of liquidity disclose more information in order to lower the conflict between shareholders and creditors (Abd-Elsalam, 1999). Contradictions not only occur among theories but also among empirical results. For example Nandi and Ghosh 
(2012) revealed a positive connection between liquidity ratio and disclosure for Canadian firms (this evidence supports signaling). Conversely, Al shammari et al. (2008) supported the agency theory prospective, because they found that Spanish firms undergoing a low liquidity ratio revealed more financial disclosure. Nevertheless Hancock and Izan (2006) did not support either of those theories, as they found no relationship between liquidity and the level of disclosure.

$\mathrm{H}_{5}$ : There is a significant positive relationship between liquidity and the level of voluntary disclosure found in annual reports.

\subsection{Corporate Governance Related Variables}

\subsubsection{Independent Directors}

One of the variables increasingly used in recent disclosure studies is the ratio of independent directors on the board. Inclusion of outside directors on the board might enhance the viability of the board as an internal control, prevent expropriation of security holder wealth, attenuate agency costs and create pressure for better disclosure. If independent directors on the board actually conduct their controlling and monitoring role, good corporate governance is strengthened (Chau \& Gray, 2010), boards effectiveness is enhanced (Haniffa \& Cooke, 2002), disclosure quality is improved and more information disclosure is expected. The results of previous studies are not consistent in relation to the association between proportion of independent directors on the board and the level of voluntary disclosure. Some studies found positive significant association between the two variables (Chau \& Gray, 2010; Rouf, 2012), some studies found negative association (Gul \& Leung, 2004) and some others found no significant association (Haniffa \& Cooke, 2002; Alves et al., 2012).

$\mathrm{H}_{6}$ : There is a significant positive relationship between the proportion of independent directors on the board and the level of voluntary disclosure found in annual reports.

\subsubsection{Audit Committee Size}

Limited research has been undertaken to investigate the relationship between voluntary disclosure and the features of audit committee. Forker (1992) was the first paper to propose this relationship. The author suggests that the audit committee is as an effective monitoring mechanism to enhance the quality of corporate disclosure and reduce agency costs. Furthermore, Ho and Wong (2001) argue that the existence of an audit committee significantly influences the amount of corporate disclosure. In others empirical studies (Barako et al., 2006) conclude the predictable positive connection between audit committee size and level of voluntary disclosure.

$\mathrm{H}_{7}$ : There is a positive relationship between audit committee size and the level of voluntary disclosure found in annual reports.

\subsubsection{Board Size}

Board size is a significant corporate governance characteristic. Board size has a positive effect on the level of corporate voluntary disclosure (Samaha et al., 2012; Nadndi \& Ghosh, 2012; Hassan, 2013). Larger boards are more efficient for corporate performance since they have a wide range of collective experience and expertise that may assist in making better decisions.

$\mathrm{H}_{8}$ : There is positive relationship between board size and the level of voluntary disclosure found in annual reports.

\subsubsection{Ownership Structure}

Ownership structure is one of the mechanisms that associate the interest of shareholders and mangers. unlike the UK and the US which have dispersed ownership, ownership in Jordanian public listed companies are much more concentrated or owned by the insider, so that's why this study uses managerial ownership as proxy to measure ownership structure. Previous studies found a positive relationship between managerial ownership and disclosure in the US (Nagar et al., 2003) in Malaysia (Mohd-Nasir \& Weetman, 2006) and in Hong Kong (Leung \& Horwitz, 2004).

$\mathrm{H}_{9}$ : There is a significant a positive a relationship between managerial ownership and the level of voluntary disclosure found in annual reports.

\subsubsection{Control Variables}

To test the main hypotheses, this thesis includes a number of control variables (Industry type, auditing firm, listing status). These control variables are included, as they are reported in the literature to be associated with voluntary disclosure. 


\section{Methodology}

\subsection{Sample and Data Collection}

To be included in the sample, listed firms must satisfy the following selection criteria in order to test the hypotheses developed:

- Firms must be listed continuously on ASE in (2010-2012) three years' annual reports are available for examination.

- Financial firms are excluded from the sample, as they are subject to a different accounting system and disclosure requirements in Jordan.

\subsection{Measurement of the Level of Voluntary Disclosure}

To determine the disclosure level of voluntary items, earlier studies have utilized two approaches: weighted (Ho \& Wong, 2001) or unweighted index (Chau \& Gray, 2010). The utilization of a weighted disclosure index has been criticized since it may introduce a bias towards a particular user orientation (Barako et al., 2006), and is based on a subjective importance rating ranked by the researchers (Alsaeed, 2006). Therefore, we adopted unweighted index in this research, this approach is most appropriate when no importance is given to any specific user groups (Hossain \& Hammami, 2009). The items of information are numerically scored on a dichotomous basis. According to the unweighted disclosure approach, a firm is scored (1) for an item disclosed in the annual report and (0) if it is not disclosed. The total voluntary disclosure index is then computed for each sample firm as a ratio of the total disclosure score to the maximum possible disclosure by the firm. The disclosure index for each firm is then expressed as a percentage.

\subsection{Model Specification}

A secondary method for data collection has been used in this study. The data set for variables is collected from financial information available on the websites of companies. The information on independent as well as control variables is also collected from annual reports of the companies. Ordinary Least Squares (OLS) regression is employed to examine the relationship between variables.

$$
\begin{gathered}
\text { Voluntary Disclosure Index }=\beta_{0}+\beta_{1} \ln A S S T+\beta_{2} L E V+\beta_{3} A G Y+\beta_{4} R O A+\beta_{5} L I Q+\beta_{6} P I N D+\beta_{7} A C S+\beta_{8} \\
B S Z E+\beta_{9} S O E+\beta_{10} I N D U+\beta_{11} B I G F O U R+\beta_{12} L S+e
\end{gathered}
$$

\subsection{Explanatory Variables}

\begin{tabular}{|c|c|c|c|c|}
\hline Hypothesis & Variables & Label & Measurement & Exp. sign \\
\hline H1 & Firm size & $\ln \mathrm{ASST}$ & $\log$ of total assets & + \\
\hline $\mathrm{H} 2$ & Leverage & LEV & Total liabilities/ Total assets & + \\
\hline H3 & Firm age & AGY & Number of years since foundation & + \\
\hline $\mathrm{H} 4$ & Profitability & ROA & Return/Total assets (ROA) & + \\
\hline H5 & Liquidity & LIQ & current assets / current liabilities & + \\
\hline H6 & Independent directors & PIND & $\begin{array}{l}\text { Number of independent directors/Total number of directors } \\
\text { on the board of directors }\end{array}$ & s \\
\hline $\mathrm{H} 7$ & Audit committee size & $\mathrm{ACS}$ & The total number of member on the audit committee & + \\
\hline H8 & Board size & BSZE & The total number of member on the Board size & + \\
\hline H9 & Ownership structure & SOE & $\begin{array}{l}\text { Percentage of equity owned by the insiders (directors, } \\
\text { managers) to all equity of the firm. }\end{array}$ & + \\
\hline Industry type & & INDU & $\begin{array}{l}\text { Dummy variable: } 1=\text { manufacturing firm and } 0=\text { Service } \\
\text { Firm. }\end{array}$ & \\
\hline Auditor type & & BIGFOUR & $\begin{array}{l}\text { Dummy variable: } 1=\text { if a firm's auditor is an international } \\
\text { audit firm ( big 4) } 0=\text { if a firm's auditor is other }\end{array}$ & \\
\hline Listing status & & LS & Dummy variable: ( $1=$ first tier, $0=$ other tier $)$. & \\
\hline
\end{tabular}

Table 1. Independent and control variables identification 


\section{Results}

\subsection{Descriptive Statistics}

\subsubsection{Extent of Voluntary Disclosure: Overall Disclosure}

Table 2 provides the descriptive statistics of the level of voluntary disclosure. The voluntary disclosure scores range from $15.4 \%$ to $83.1 \%$, with a mean score of $35.7 \%$. It can be seen from the percentage change of scores over the three periods that there is a significant positive trend of voluntary disclosure. It can be seen from Table 2 that the highest disclosure score in the sample set is $84.1 \%$ which occurred in 2012.

Table 2. Descriptive statistics of overall voluntary disclosure scores

\begin{tabular}{ccccc}
\hline Year & Mean & St. Dev. & Min & Max \\
\hline 2010 & 0.321 & 0.142 & 0.124 & 0.636 \\
2011 & 0.345 & 0.174 & 0.145 & 0.715 \\
2012 & 0.383 & 0.532 & 0.191 & 0.841 \\
Total & 0.357 & 0.135 & 0.154 & 0.831 \\
\hline
\end{tabular}

Table 3 shows the number and percentages of companies whose disclosure score is within the specified range. $8.40 \%$ companies disclose voluntary information less than of $20 \% ; 8.98 \%$ companies disclosure in the range of (21 to 30)\%. 31.30\% companies disclosure in the range of (31 to 40 )\% and 22.31 and $21.73 \%$ companies disclose voluntary information in the range of (41 to 50)\% and (51 to 60)\% respectively. $2.89 \%$ companies disclosure in the range of (61 to 70)\%; $2.60 \%$ companies disclose voluntary information in the range of (71 to $80) \% ; 1.73 \%$ companies disclose more than $80 \%$ voluntary information in the annual reports of listed companies of Jordan.

Table 3. Frequency distribution of voluntary disclosure scores

\begin{tabular}{ccc}
\hline Disclosure score $(\boldsymbol{\%})$ & No of cases & \% \\
\hline$<=20$ & 29 & 8.40 \\
21 to 30 & 31 & 8.98 \\
31 to 40 & 108 & 31.30 \\
41 to 50 & 77 & 22.31 \\
51 to 60 & 75 & 21.73 \\
61 to 70 & 10 & 2.89 \\
71 to 80 & 9 & 2.60 \\
$>80$ & 6 & 1.73 \\
\hline
\end{tabular}

Table 4. The descriptive statistics for dependent and Independent variables

\begin{tabular}{cccccc}
\hline Variable & N & Mean & St. Dev. & Min & Max \\
\hline $\begin{array}{c}\text { Dep. Variable } \\
\text { VD }\end{array}$ & 345 & 0.357 & 0.135 & 0.154 & 0.831 \\
Indep. Variable & & & & \\
LnASST & 345 & 42.264 & 1.836 & 21.335 & 63.554 \\
LEV & 345 & 34.972 & 34.282 & 0.312 & 247.690 \\
AGY & 345 & 15.584 & 20.214 & 7.000 & 54.000 \\
ROA & 345 & 0.162 & 0.231 & -0.167 & 0.483 \\
LIQ & 345 & 2.438 & 2.013 & 0.114 & 9.529 \\
PIND & 345 & 0.321 & 0.362 & 0.000 & 0.865 \\
ACS & 345 & 3.045 & 0.188 & 3.000 & 6.000 \\
BSZE & 345 & 8.597 & 2.219 & 5.000 & 14.000 \\
SOE & 345 & 0.484 & 0.223 & 0.061 & 0.986 \\
\hline
\end{tabular}


Table 4 shows the descriptive statistics of the independent variables examined in explaining the variability in voluntary disclosure practices. The results from the disclosure index indicate that the level of average voluntary disclosure in the sample companies is $35.7 \%$ the highest score achieved by a firm is $83.1 \%$ and the lowest score is $15.4 \%$ with a standard deviation of $0.13 \%$. So the firms are widely distributed with regard to voluntary disclosure.

\subsection{Univariate Analysis}

Table 5 presents the correlation matrix of the variables, it shows a number of strong correlations between some explanatory variables. This implies the possibility of Multicollinearity problems. The largest reported correlation value among the variables as shown in Table $5(0.545)$ was between listing status and board independence variable. However, this value is still lower than the critical value of 0.80 according to (Cooper \& Schindler, 2008). Hence, Multicollinearity between the independent variables is not considered a serious problem.

Table 5. Correlation statistics for variables used in the analyses

\begin{tabular}{|c|c|c|c|c|c|c|c|c|c|c|c|c|c|}
\hline Variables & VD & InASST & LEV & AGE & ROA & LIQ & PIND & ACS & BSZE & SOE & INDU & BIG4 & $\mathbf{L S}$ \\
\hline VD & 1.000 & & & & & & & & & & & & \\
\hline $\ln \mathrm{ASST}$ & $0.411^{* *}$ & 1.000 & & & & & & & & & & & \\
\hline LEV & $0.106^{*}$ & $0.331^{* *}$ & 1.000 & & & & & & & & & & \\
\hline AGY & $0.113^{*}$ & 0.047 & 0.026 & 1.000 & & & & & & & & & \\
\hline ROA & $0.212 * *$ & $0.322 * *$ & 0.024 & 0.004 & 1.000 & & & & & & & & \\
\hline LIQ & $0.116^{*}$ & -0.081 & $0.342 * *$ & $0.112^{*}$ & $0.183^{* *}$ & 1.000 & & & & & & & \\
\hline PIND & $-0.243 * *$ & $0.165^{*}$ & 0.066 & 0.034 & -0.065 & 0.048 & 1.000 & & & & & & \\
\hline ACS & $0.127^{*}$ & $0.134 *$ & 0.081 & $0.271 * *$ & 0.075 & 0.028 & 0.002 & 1.000 & & & & & \\
\hline BSZE & $0.313 * *$ & $0.296^{* *}$ & $0.203^{* *}$ & 0.065 & 0.016 & $0.113 *$ & $0.433^{* *}$ & 0.053 & 1.000 & & & & \\
\hline SOE & $-0.261 * *$ & $-0.231 * *$ & 0.076 & $-0.342 * *$ & -0.068 & -0.051 & $-0.179^{*}$ & 0.023 & $-0.186^{* *}$ & 1.000 & & & \\
\hline INDU & $0.111^{*}$ & 0.013 & $0.175^{* *}$ & $0.234 * *$ & $-0.136^{*}$ & $-0.128^{*}$ & $0.144^{*}$ & 0.016 & $0.275^{* *}$ & 0.051 & 1.000 & & \\
\hline BIG4 & $0.182^{* *}$ & $0.138^{*}$ & $0.221^{* *}$ & $0.197 * *$ & 0.051 & -0.013 & $0.126^{*}$ & -0.053 & $0.133^{*}$ & 0.049 & $0.285^{* *}$ & 1.000 & \\
\hline LS & $0.116^{*}$ & 0.037 & 0.034 & $0.177 * *$ & 0.057 & 0.038 & $0.545^{* *}$ & 0.043 & $0.118^{*}$ & 0.015 & 0.011 & 0.006 & 1.000 \\
\hline
\end{tabular}

Note. $(* *)$ indicates significant at $1 \%$ level; * indicates significance at $5 \%$ level (two-tailed).

\subsection{Multivariate Analysis}

The $\mathrm{R}^{2}$ measures how much variation in the response variable the predictors in the model can explain. For this research as shows in Table 6 the $\mathrm{R}^{2}$ are approximately 54.1\%, 58.8\%, and $61.3 \%$ for the year 2010 to 2012, respectively. The $\mathrm{R}^{2}$ is low for the year 2010 . However, the $\mathrm{R}^{2}$, increased significantly in (2011-2012).

The adjusted $\mathrm{R}^{2}$ improved approximately from $52 \%$ in 2010 to $57 \%$ in 2011 and $59 \%$ in 2012. Consequently, the explanatory powers of the model increased over the years. However, the year 2012 seems to produce a better explanatory model compared to 2011 and 2010. Furthermore, Table 6 shows F-statistic with its significance. This is the goodness of fit test, which indicates, overall, the quality of the models to predict the outcome variable. The models of 2010, 2011 and 2012 have a significant value below 0.10. This implies that the models are statistically significant. Consequently, at least $90 \%$ confidence exists that the models can explain the dependent variable. All of these values suggest that a significant percentage of the variation in voluntary disclosure can be explained by the variations in the whole set of independent variables.

The results for 2010, 2011 and 2012 nearly same where the coefficient shows a positive and significant relationship with the VD for some variables, which implies that (LNASST, AGE, ROA, ACS, BSIZE, LIQ) have a positive effect on the level of voluntary disclosure. This is in contrast with was hypothesized. This implies that, the higher (LNASST, AGE, ROA, ACS, BSIZE, LIQ), the higher level of voluntary disclosure. The coefficient of (PIND, SOE) has a negative and significant relationship at level of 0.05 with the level of voluntary disclosure. This implies that, the higher (PIND, SOE), the lower level of voluntary disclosure. Furthermore, the coefficient of (LEV) does not have significant influence the level of voluntary disclosure. 
Moreover, all control variables have a positive and significant relationship with the level of voluntary disclosure. All hypothesizes are supported by the results of the regression model of 2010-2011-2012 beyond (H2, H6, H9) Where the results do not support hypothesis (2) which suggest that: A positive relationship exists between (LEV) and the level of voluntary disclosure. The (LEV) has a positive relationship with the level of voluntary disclosure and is not significant, implying that with a $90 \%$ level of confidence, cannot state that the estimate is true.

The results also do not support hypothesis (6) and hypothesis (9) which suggest that: A positive relationship exists between each of (PIND), (SOE) and the level of voluntary disclosure. The (PIND), (SOE) have a negative and significant relationship at level of 0.05 with the level of voluntary disclosure.

Table 6. Multiple regression results (year-wise)

\begin{tabular}{|c|c|c|c|c|c|c|c|c|}
\hline \multirow[t]{2}{*}{ Variables } & \multicolumn{2}{|c|}{ Model (2010) } & \multicolumn{2}{|c|}{ Model (2011) } & \multicolumn{2}{|c|}{ Model (2012) } & \multicolumn{2}{|c|}{ Full model } \\
\hline & Coeff. & p-value & Coeff. & p-value & Coeff. & p-value & Coeff. & p-value \\
\hline Intercept & 4.656 & 0.000 & 5.876 & 0.000 & 5.476 & 0.000 & 5.236 & 0.000 \\
\hline \multicolumn{9}{|c|}{ Firm characteristics related variables } \\
\hline $\ln \mathrm{ASST}$ & 0.165 & $0.000 * * *$ & 0.198 & $0.000 * * *$ & 0.287 & $0.000 * * *$ & 0.178 & $0.000 * * *$ \\
\hline LEV & 0.029 & 0.137 & 0.021 & 0.149 & 0.065 & 0.121 & 0.043 & 0.153 \\
\hline AGY & 0.081 & $0.023^{* *}$ & 0.073 & $0.027 * *$ & 0.086 & $0.014 * *$ & 0.083 & $0.019 * *$ \\
\hline ROA & 0.063 & $0.064^{*}$ & 0.046 & $0.076^{*}$ & 0.085 & $0.038 * *$ & 0.072 & $0.056^{*}$ \\
\hline LIQ & 0.042 & $0.068^{*}$ & 0.038 & $0.017 * *$ & 0.054 & $0.011 * *$ & 0.048 & $0.014 * *$ \\
\hline \multicolumn{9}{|c|}{ Corporate governance related variables } \\
\hline PIND & -0.023 & $0.024 * *$ & -0.036 & $0.041 * *$ & -0.043 & $0.049 * *$ & -0.033 & $0.045^{* *}$ \\
\hline ACS & 0.074 & $0.014 * *$ & 0.068 & $0.049 * *$ & 0.047 & $0.051 *$ & 0.058 & $0.041 * *$ \\
\hline BSZE & 0.064 & $0.037 * *$ & 0.026 & $0.074 *$ & 0.053 & $0.043 * *$ & 0.030 & $0.076^{*}$ \\
\hline SOE & -0.053 & $0.032 * *$ & -0.018 & $0.027 * *$ & -0.056 & $0.043 * *$ & -0.041 & $0.024 * *$ \\
\hline \multicolumn{9}{|c|}{ Control variables } \\
\hline INDU & 0.128 & $0.011 * *$ & 0.114 & $0.012 * *$ & 0.112 & $0.034 * *$ & 0.103 & $0.021 * *$ \\
\hline BIGFOUR & 0.076 & $0.039 * *$ & 0.157 & $0.018 * *$ & 0.025 & $0.064 *$ & 0.047 & $0.024 * *$ \\
\hline LS & 0.031 & $0.065^{*}$ & 0.046 & $0.039 * *$ & 0.156 & $0.000 * * *$ & 0.038 & $0.041 * *$ \\
\hline F-statistic & 10.974 & & 13.423 & & 15.756 & & 28.367 & \\
\hline F-sig & 0.000 & & 0.000 & & 0.000 & & 0.000 & \\
\hline $\mathbf{R}^{2}$ & 0.541 & & 0.588 & & 0.613 & & 0.584 & \\
\hline Adjusted $\mathbf{R}^{2}$ & 0.521 & & 0.574 & & 0.591 & & 0.570 & \\
\hline
\end{tabular}

Note. $(* * *)$ indicates significance at $1 \%$ level; $(* *)$ indicates significance at $5 \%$ level and $(*)$ indicates significance at $10 \%$ level. The reported p-values are all two-tailed except intercept.

\subsection{Sensitivity Analysis}

A number of sensitivity tests are performed, in which some alternative measures, for some variables, are used. Generally, the results of sensitivity tests are consistent with reported regression results.

\subsubsection{Alternative Measures}

Using the number of employees as an alternative measure of firm size. Since many variables used in the regression analyses are correlated with firm size as measured by log of total assets size, firm size as one of firm characteristic variables can also measure by number of employees. (Because as we have seen before this variable has high correlation nearly with all variables, we undertake the following sensitivity analyses to test whether the study's main results are driven by size effects.). The findings additional regressions reflect the same results, as they reflect a positive and significant association between Firm size (number of employees) and dependent variables (Coeff. $=0.067$ and $\mathrm{p}$-value $=0.041 * *$ ). 
As we have seen before within Jordanian listed firms, higher leverage firm's is not necessary to provide extra information beyond mandatory disclosure requirements and as we know besides the ratio of total debt (liabilities) to total assets, other leverage measure considered in this study include the ratio of long term debt to owners' equity. This alternative leverage measure is significantly and negatively (Coeff. $=-0.016$ and p-value $=0.071 *$ ) associated with the level of voluntary disclosure.

Table 7. Sensitivity analysis, alternative measures

\begin{tabular}{|c|c|c|}
\hline Variable & Coeff. & p-value \\
\hline Intercept & 5.154 & 0.000 \\
\hline \multicolumn{3}{|c|}{ Firm characteristics related variables } \\
\hline EMPNUM & 0.067 & $0.041 * *$ \\
\hline LEV & -0.016 & $0.071 *$ \\
\hline AGY & 0.076 & $0.028 * *$ \\
\hline ROA & 0.059 & $0.071 *$ \\
\hline LIQ & 0.047 & $0.092 *$ \\
\hline \multicolumn{3}{|c|}{ Corporate governance related variables } \\
\hline PIND & -0.031 & $0.037 * *$ \\
\hline ACS & 0.067 & $0.048 * *$ \\
\hline BSZE & 0.058 & $0.041 * *$ \\
\hline SOE & -0.049 & $0.047 * *$ \\
\hline \multicolumn{3}{|c|}{ Control variables } \\
\hline INDU & 0.112 & $0.024 * *$ \\
\hline BIGFOUR & 0.071 & $0.047 * *$ \\
\hline LS & 0.024 & $0.069^{*}$ \\
\hline F-statistic & 26.428 & \\
\hline F-sig & 0.000 & \\
\hline $\mathbf{R 2}$ & 0.562 & \\
\hline Adjusted R2 & 0.554 & \\
\hline
\end{tabular}

\section{Conclusion and Recommendations}

The answer for research question 1: The evidence reported that in aggregate, the general level of voluntary disclosure by Jordanian listed firms is arguably low (with the mean of 38.6\%). The results support the expectation that the level of voluntary disclosure in Jordan as an emerging capital market with secretive culture is low, however. It is also found that companies manage their voluntary disclosure policy which is not a random practice but subject to certain influences. Maybe one of the reasons for this low level of voluntary disclosure is the lack of effective regulation and law enforcement by the stock exchange regulatory bodies may contribute to the low level of information transparency, particularly voluntary disclosure. In general, we can indicate that there is room to improve the transparency of the Jordanian capital market. The study highlights the possibility of cooperation between the capital market authority and all interested parties to enhance transparency by providing pattern of voluntary disclosure and corporate governance practice.

The answer for research question 2: The evidence reported that in aggregate, The statistical results indicate that concerning on firm characteristics, the findings support the evidence from the majority of prior literature of the positive relationship between total voluntary disclosure and each of firm size, firm age, profitability and liquidity. However, leverage as measured by the ratio of total debt (liabilities) to total assets was not related to total voluntary disclosure and negative association with total voluntary disclosure as measured by the ratio of long term debt to owners' equity. Concerning on corporate governance attributes do affect the level of voluntary disclosure in firm annual reports. Four variables were found to be associated with the level of total voluntary 
disclosure in firm annual reports; two positively and two negatively. Board size and audit committee size, were found to have positive significant association with the level of total voluntary disclosure. However, the percentage of independent directors and ownership structure were found to be negatively associated with total voluntary disclosure.

The focus of this study was limited to one source of information, the annual report. Although annual reports are considered to be the most important source of information, there are other sources of information in Jordan that could be useful for decision making, such as interim reports, ASE publications, prospectuses, internet sources and financial press releases. These sources of information sources were not included in this study and might form important data sources for future research disclosure studies. Moreover, the recent developments in technology and communications suggest a need to pay more attention to internet sources of information. This study focused upon one country, mainly Jordan. An extension of the study could be to compare disclosure between Jordan and other developing countries in the Middle East. Collecting data for more companies in different countries, especially those with different disclosure regulations would enhance the validation of the results in this study and would determine the differences and similarities in policy makers' decisions across the region. Such studies would be useful to the literature on comparative international accounting.

\section{References}

Abd-Elsalam, H. (1999). The introduction and application of international accounting standards to accounting disclosure regulations of a capital market in developing country: The case of Egypt. (PhD Thesis), Herriot-Watt University, UK.

Aksu, M., \& Kosedag, A. (2006). Transparency and disclosure scores and their determinants in Istanbul Stock Exchange. Corporate Governances, 14(4), 277-296. http://dx.doi.org/10.1111/j.1467-8683.2006.00507.x

Allegrini, M., \& Greco, G. (2011). Corporate boards, audit committees and voluntary disclosure: Evidence from Italian listed companies. Journal of Management and Governance, 17(1), 187-216. http://dx.doi.org/10.1007/s10997-011-9168-3

Alsaeed, K. (2006). The association between firm-specific characteristics and disclosure: The case of Saudi Arabia. Managerial Auditing Journal, 21(5), 476-496. http://dx.doi.org/10.1108/02686900610667256

Al-Shammari, B. (2008). Voluntary disclosure in Kuwait corporate annual reports. Review of Business Research, 8(1), 10-30. http://dx.doi.org/ 10.1016/j.sbspro.2014.03.686

Alves, H., Rodrigues, A., \& Canadas, N. (2012). Factors influencing the different categories of voluntary disclosure in annual reports, an analysis of Iberian Peninsula listed companies. Tekhne, 10(1), 15-26. http://dx.doi.org/10.1016/S1645-9911(12)70003-8

Barako, D., Hancock P., \& Izan, I. (2006). Factors influencing voluntary corporate disclosure by Kenyan companies. Corporate Governance: An International Review, 14(2), 107-125. http://dx.doi.org/10.1111/j.1467-8683.2006.00491.x

Bhayani, S. (2012). Association between firm-specific characteristics and corporate disclosure: The case of India. International Conference on Business, Economics, Management and Behavioral Science, Dubai 7-8, 2012.

Chau, G., \& Gray, S. (2010). Family ownership, board independence and voluntary disclosure: Evidence from Hong Kong. Journal of International Accounting, Auditing and Taxation, 19(2), 93-109. http://dx.doi.org/10.1016/j.intaccaudtax.2010.07.002

Cooper, D. R., \& Schindler, P. (2008). Business research methods (10th ed.). Boston: McGraw-Hill Irwin.

Forker, J. (1992). Corporate governance and disclosure quality. Accounting and Business Research, 22(86), 111-124. http://dx.doi.org/10.1080/00014788.1992.9729426

Ghazali, M., \& Weetman, P. (2006). Perpetuating traditional influences: Voluntary disclosure in Malaysia following the economic crisis. Journal of International Accounting, Auditing and Taxation, 15(2), 226-248. http://dx.doi.org/10.1016/j.intaccaudtax.2006.08.001

Glaum, M., \& Street, D. (2003). Compliance with the disclosure requirement of German's new market, IAS Versus US GAAP. Journal of International Financial Management and Accounting, 14(1), 64-100. http://dx.doi.org/10.1111/1467-646X.00090

Gul, F., \& Leung, S. (2004). Board leadership, outside directors' expertise and voluntary corporate disclosures. $\begin{array}{lllll}\text { Journal of Accounting and Public Policy, 23(5), 379. } & \text { 351-37. }\end{array}$ 
http://dx.doi.org/10.1016/j.jaccpubpol.2004.07.001

Hajji, G. (2013). The quality and determinants of voluntary disclosure in annual reports of Shariah compliant companies in Malaysia. Humanomics, 29(1), 24-42. http://dx.doi.org/10.1108/08288661311299303

Haniffa, R., \& Cooke, T. (2002). Culture, corporate governance and disclosure in Malaysian corporations. Abacus, 38(3), 317-349. http://dx.doi.org/10.1111/1467-6281.00112

Hassan, M. (2013). Corporate governance characteristics and voluntary disclosure: The case of UAE listed corporations. The 2013 IBEA, 20-23 March 2013, Bangkok, Thailand.

Ho, S., \& Wong, K. (2001). A study of the relationship between corporate governance structure and the extent of voluntary disclosure. Journal of International Accounting, Auditing and Taxation, 10, 139-156. http://dx.doi.org/10.1016/S1061-9518(01)00041-6

Hossain, M., \& Hammami, H. (2009). Voluntary disclosure in the annual reports of an emerging country: The case of Qatar. Advances in Accounting, 25(2), 255-265. http://dx.doi.org/10.1016/j.adiac.2009.08.002

Inchausti, B. (1997). The influence of company characteristics and accounting regulation on information disclosed by Spanish firms. European Accounting Review, 6(1), 45-68. http://dx.doi.org/10.1080/096381897336863

Jensen, M., \& Meckling, W. (1976). Theory of the firm: Managerial behavior, agency costs and ownership $\begin{array}{lllll}\text { structure. Journal of } & \text { Financial }\end{array}$ http://dx.doi.org/10.1016/0304-405X(76)90026-X

Kolsi, M. (2012). The determinants of corporate voluntary disclosure: Evidence from the Tunisian capital market. Journal of Accounting Research \& Audit Practices, 4, 49-68.

Nagar, V., Nanda, D., \& Wysocki, P. (2003). Discretionary disclosure and stock-based incentives. Journal of Accounting and Economics, 34, 283-309. http://dx.doi.org/10.1016/S0165-4101(02)00075-7

Nandi, S., \& Ghosh, S. (2012). Corporate governance attributes, firm characteristics and the level of corporate disclosure: Evidence from the Indian listed firms. Decision Science Letters, 2(2012), 45-58. http://dx.doi.org/10.5267/j.dsl.2012.10.004

Owusu, S. (1998). The impact of corporate attributes on the extent of mandatory disclosure and reporting by listed companies in Zimbabwe. The International Journal of Accounting, 33(5), 605-631. http://dx.doi.org/10.1016/S0020-7063(98)90015-2

Samaha, K., Dahawy, K., Abdel-Meguid, A., \& Abdallah, S. (2012). Propensity and comprehensiveness of corporate internet reporting in Egypt: Do board composition and ownership structure matter? International Journal of Accounting and Information Management, 20(2), 142-170. http://dx.doi.org/10.1108/18347641211218452

\section{Copyrights}

Copyright for this article is retained by the author(s), with first publication rights granted to the journal.

This is an open-access article distributed under the terms and conditions of the Creative Commons Attribution license (http://creativecommons.org/licenses/by/3.0/). 